Pomáhajúce profesie, roč. 1, č. 2, 2018, 49-56

\title{
VÝSKYT CIEVNEJ MOZGOVEJ PRÍHODY U PACIENTOV HOSPITALIZOVANÝCH VO FAKULTNEJ NEMOCNICI V NITRE
}

\author{
Dana Brázdilová \\ Katedra klinických disciplín a urgentnej medicíny FSVaZ UKF Nitra \\ dbrazdilova@ukf.sk
}

\begin{abstract}
Abstrakt: Ciel': Autorka sa práci venuje Fabryho chorobe ako multisystémovému ochoreniu, ktoré môže mat' ako jeden z predispozičných faktorov vplyv na výskyt cievnej mozgovej príhody. Metódy: Autorka si za ciel' stanovila spracovat' retrospektívnou analýzou dokumentov súbor pacientov hospitalizovaných vo FN Nitra v určenom časovom období. Výsledky: Z celkového počtu 666 respondentov, ktorí v roku 2017 prekonali CMP a boli hospitalizovaní vo FN v NR bolo 571 respondentov (85,74\%) $\mathrm{s}$ ischemickou CMP a 89 respondentov $(13,36 \%) \mathrm{s}$ hemoragickou CMP a 6 respondentov $(0,90 \%)$ mali CMP bližšie neurčenú ako krvácanie alebo infarkt. Z hl'adiska pohlavie sme zistili, že ischemickú CMP prekonalo 323 respondentov $(56,57 \%)$ mužského pohlavia a 248 respondentov $(43,43 \%)$ ženského pohlavia. Z celkového počtu 666 respondentov súboru A, bolo hospitalizovaných 627 respondentov (94,14\%) s novozistenou CMP a u 39 respondentov (5,86\%) CMP v roku 2017 zrecidivovala. Záver: Akútne mozgové infarkty sú tretou najčastejšou príčinou smrti a najčastejším dôvodom predčasnej invalidity. Ročná incidencia stúpa s pribúdajúcim vekom. U mladých l'udí však musíme pamätat' aj na iné ako obvyklé príčiny a jednou z nich je aj Fabryho choroba.
\end{abstract}

Klúčové slová: Fabryho choroba, Cievna mozgová príhoda, Ischemická cievna mozgová príhoda, Hemoragická cievna mozgová príhoda, $\alpha$-galaktozidáza A, Glykosfingolipidy

\section{ÚVOD}

„Náhle cievne mozgové príhody (NCMP) sú tret'ou najčastejšou príčinou smrti a najčastejšou príčinou invalidity u dospelých pacientov" (Gogolák, 2010, str. 56). Výskyt cievnych mozgových príhod (d’alej CMP) má v celosvetovom meradle, rovnako ako aj na Slovensku, vzostupnú tendenciu. Hoci dôvody nárastu prevalencie nie sú úplne známe dôležitú úlohu zohráva starnutie populácie (Kalvach, 2010). V prednemocničnej neodkladnej starostlivosti sa s pacientmi s cievnou mozgovou príhodou stretávame pomerne často. Na dosiahnutie zmiernenia ich následkov a zníženia úmrtnosti je potrebné, aby sa včas rozpoznali a okamžite liečili. S víziou tejto perspektívy boli vypracované odporúčania pre postup starostlivosti o takéhoto pacienta ešte pred príchodom do zdravotníckeho zariadenia (Kalvach, 2010; Brozman, 2008). Pri analýze časových intervalov sa potvrdzuje, že najväčšie zdržanie spôsobuje neskoré rozpoznanie príznakov a oneskorené volanie urgentnej linky (Brozman, 2014). Pri prijatí do zdravotníckeho zariadenia je nutné stanovit' v čo najkratšom čase, či ide o tranzitórny ischemický atak/mozgový infarkt, subarachnoidálne alebo intracerebrálne krvácanie, aby bola pacientom poskytnutá okamžitá a adekvátna liečba, ktorá je obzvlášt' v prípade mozgového infarktu časovo limitovaná vel'mi krátkym terapeutickým oknom ako aj adekvátna ošetrovatel'ská starostlivost' (Solgajová et al., 2016). Mozgový infarkt je najčastejším typom príhody, tvorí až 80 \% iktov a vzniká pri stenóze, resp. oklúzii mozgovej artérie v dôsledku lokálneho nedostatku krvi a metabolických substrátov (Gogolák, 2010). „Najnovšie analýzy potvrdzujú, že rýchlost’ podania liečby je najrozhodujúcejší faktor úspešnej rekanalizácie a dobrého 
klinického výsledku“ (Brozman, 2014, str. 4). Jedným z možných dôvodov výskytu tohto typu CMP môže byt' aj multisystémové ochorenie nazývané ako Fabryho choroba (d’alej FCH) a to hlavne v mladšom veku. Fabryho choroba je vrodené ochorenie charakterizované metabolickým defektom degradácie glykosfingolipidov (hlavne globotriaozyl-ceramidu GL-3, menej galaktozylglukozylceramidu), vedúce $\mathrm{k}$ ich ukladaniu v lyzozómoch organizmu. Následne vzniká poškodenie štruktúry a funkcie viacerých orgánov, najmä však kardiovaskulárneho systému a obličiek. FCH patrí do skupiny ochorení označovaných ako „orphan diseases“, teda zriedkavo sa vyskytujúce ochorenia. Výskum a vývoj liekov pre relatívne malé množstvo pacientov s takýmito ochoreniami je finančne vel’mi náročný (Spada, Pagliardini, Yasuda, 2006).

Fabryho choroba (d’alej FB) „rovnako označovaná ako Fabryho-Andersonova choroba (či deficiencia alfa-galaktosidázy A, deficit ceramid trihexosidázy, OMIM 301500) je vzácne geneticky podmienené ochorenie, ktoré bolo popísané už pred viac ako 100 rokmi“ (Lacina, Kodet, 2017, str. 58). V roku 1898 dvaja dermatológovia nezávisle na sebe, William Anderson z Anglicka a Johannes Fabry z Nemecka, opísali pacientov s kožnými zmenami, ktoré nazvali angiokeratómy. Preto sa v literatúre môžeme stretnút' aj s názvom Fabryho-Andersonova choroba, dnes sa však častejšie používa termín Fabryho choroba (Kákošová, 2007). Ide o dedičné multiorgánové ochorenie so závažnou prognózu (Goláň, 2012). Genetickou analýzou rodokmeňa postihnutých jedincov bolo určené, že ide o ochorenie viazané na X chromozóm a že ide o vlohu s prevažne recesívnym spôsobom dedičnosti (Lacina, Kodet, 2017). Klinickými prejavmi, pri ktorých by sa malo pamätat' na prítomnost' FCH sú najčastejšie typické cievne lézie na koži a slizniciach charakteru angiokeratomov (angiokeratoma corporis diffusum); poruchy kožných sudorimotorických funkcií (tj. poruchy potenia); periodická výrazná bolest' v akrách (koži a svaloch končatín, akroparestezie); typické zmeny rohovky a šošovky (cornea verticillata); iktus nejasného pôvodu; renálna insuficiencia nejasného pôvodu (vrátane nevysvetlitel'nej proteinúrie a mikroalbuminúrie) a l'avostranná ventrikulárna hypertrofie nejasného pôvodu (Lacina, Kodet, 2017; Goláň, 2012).

\section{Ciel'}

Hlavný ciel' príspevku bolo spracovat' súbor pacientov hospitalizovaných vo FN Nitra pre cievnu mozgovú príhodu v určenom časovom období. Zamerali sme sa na rozbor jednotlivých sledovaných kritérií s ciel’om zistit' výskyt Fabryho choroby v našich podmienkach.

Chceli sme zistit':

Akú skupinu pacientov s prekonanou CMP hospitalizovaných vo FN v Nitre tvoria pacienti $\mathrm{s}$ ischemickou a hemoragickou CMP.

Akú skupinu pacientov s prekonanou CMP tvoria pacienti s ischemickou CMP hospitalizovaných vo FN v Nitre privezených ZZS, ktorí podstúpili výkon v Kardiocentre (d’alej KC) v Nitre.

Akú skupinu pacientov s prekonanou CMP hospitalizovaných vo FN v Nitre tvoria pacienti $s$ diagnosticky preukázanou prítomnost' Fabryho choroby prostredníctvom vyšetrenia suchej kvapky krvi.

\section{METÓDY}

\section{Výskumný súbor a metodika}

Zber empirických dát z klinickej praxe potrebných pre výskum bol realizovaný vo Fakultnej nemocnici v Nitre na Neurologickej klinike. Respondenti boli do výskumu vyberaní zámerne na základe určujúceho kritéria, ktorými bola potvrdená lekárska diagnóza CMP. Výberový súbor tvorili pacienti, ktorí prekonali CMP a boli hospitalizovaní vo FN v Nitre v období od 1. 1. 2017 do 
31. 12. 2017. Výberový súbor bol rozdelený do dvoch skupín. Prvú skupinu (súbor A) tvorili všetci pacienti hospitalizovaní vo FN v Nitre v sledovanom období s potvrdenou lekárskou diagnóza CMP. Druhú skupinu (súbor B) tvorili pacienti so súvisiacimi faktormi. Hlavným kritériom pre zaradenie respondenta do súboru B bola prekonaná CMP, veková hranica pri výskyte CMP a vyšetrenie suchej kvapky krvi na FCH. V príspevku sa venujeme výsledkom súvisiacim so súborom B. Celkový počet respondentov zaradených do výskumu tvoril 666 respondentov súboru A a 39 respondentov súboru B. Zo spomínanej vzorky A bolo 376 mužov (56,46\%) a 290 žien (43,54\%). Zo spomínanej vzorky B bolo 27 mužov ( 69,23\%) a 12 žien (30,77\%). Priemerný vek respondentov bol 50 rokov, pričom najmladší mal 26 rokov a najstarší mal 70 rokov. Najväčšiu vekovú skupinu zo súboru B tvorili respondenti vo vekovom rozpätí 50 - 59 rokov $(51,28 \%)$.

Výskum sme realizovali v časovom horizonte mesiacov január - apríl 2018. V mesiaci december 2017 sme požiadali Etickú komisiu pri FN Nitra o možnost' realizácie výskumu. Žiadosti bolo kladne vyhovené. Následne sme zostavili kritériá pre zber údajov za sledované časové obdobie, ktoré sme definovali a spracovali sledované jednotlivé štatistické jednotky. Výsledky sme percentuálne i kvantitatívne spracovali.

\section{VÝSLEDKY A DISKUSIA}

Z hl'adiska zamerania nášho výskumu sme sa sústredili na stanovenie celkového počtu prekonaných CMP u pacientov hospitalizovaných vo FN v Nitre v sledovanom období v roku 2017 s prihliadnutím na rôzne demografické a klinické faktory.

Pre naplnenie ciel’a sme realizovali retrospektívny výskum na vzorke respondentov označených ako súbor A. Išlo o 666 respondentov, ktorí boli v sledovanom období od januára do decembra 2017 hospitalizovaní vo FN v Nitre. Podl’a MKCHO sme do súboru zámerne vybrali respondentov s diagnózou I60, I61, I62, I63 a I64. V súbore nie sú zaradení pacienti hospitalizovaní s diagnózou G45, nakol'ko nejde jednoznačne o CMP.

Našim prvým ciel'om bolo zistit' výskyt CMP u pacientov hospitalizovaných vo FN v Nitre v sledovanom období s prihliadnutím na rôzne demografické a klinické faktory.

Tabul'ka 1 Rozdelenie všetkých CMP za roku 2017

\begin{tabular}{lll}
\hline Typ CMP & $\mathrm{n}$ & $\%$ \\
\hline ischemická & 571 & $85,74 \%$ \\
\hline hemoragická & 89 & $13,36 \%$ \\
\hline bližšie neurčená CMP & 6 & $0,90 \%$ \\
\hline Spolu & $\mathbf{6 6 6}$ & $\mathbf{1 0 0 , 0 0 \%}$ \\
\hline
\end{tabular}




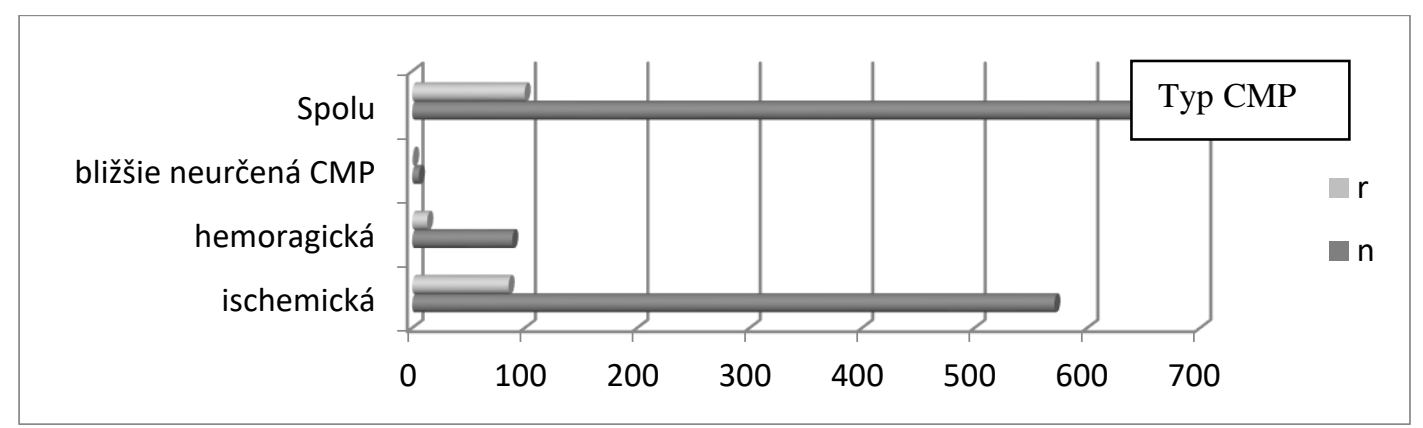

Graf 1 Rozdelenie všetkých CMP za roku 2017

Z celkového počtu 666 respondentov, ktorí v roku 2017 prekonali CMP a boli hospitalizovaní vo FN v NR bolo 571 respondentov (85,74\%) s ischemickou CMP a 89 respondentov $(13,36 \%)$ s hemoragickou CMP a 6 respondentov $(0,90 \%)$ mali CMP bližšie neurčenú ako krvácanie alebo infarkt. Z hl'adiska pohlavie sme zistili, že ischemickú CMP prekonalo 323 respondentov $(56,57 \%)$ mužského pohlavia a 248 respondentov $(43,43 \%)$ ženského pohlavia. Z celkového počtu 666 respondentov súboru $A$, bolo hospitalizovaných 627 respondentov $(94,14 \%)$ s novozistenou CMP a u 39 respondentov (5,86\%) CMP v roku 2017 zrecidivovala.

CMP je $\mathrm{z}$ 80-85 \% podmienené ischemicky a $\mathrm{z}$ 15-20 \% intracerebrálnym alebo subarachnoidálnym krvácaním. Z časového hl'adiska môže íst' o tranzientného ischemického ataku (tiež označovaný ako TIA), reverzibilný ischemický deficit (tiež označovaný ako RIND) alebo trvalý neurologický výpadok ako mozgový infarkt, nazývaný aj ako „stroke in evolution“ teda infarkt, ktorý sa nad'alej vyvíja a zostáva po ňom neurologický deficit. Pri TIA ide o dočasný neurologický alebo retinálny deficit cievnej etiológie, ktorý úplne vymizne do 24 hodín. Príznaky reverzibilného neurologického deficitu vymiznú v priebehu siedmych dní (Pekárková, 2015; Školoudík, 2014; Kalvach, 2010; Modravý, 2006). Podl'a uvedenia Solgajovej et al. (2017) býva u $16 \%$ pacientov po prekonaní CMP prítomná úzkost', ktorá má výrazný negatívny vplyv na celý proces rekonvalescencie.

Z hl'adiska klasifikácie sa Fabryho choroba radí medzi jednu z príčin výskytu ischemickej mozgovej príhody, konkrétne v kategórii iné príčiny a to metabolické ochorenia s arteriopatiou (Gogolák, 2010). „Ročne vznikne na Slovensku približne 350 nových CMP na 100000 obyvatel'ov, čo je 2-3 krát viac ako vo vyspelých európskych krajinách“ (Dobiáš, 2017, s. 184). Je známe, že výskyt ischemickej CMP sa kumuluje $\mathrm{v}$ rodinách $\mathrm{s}$ pozitívnou rodinnou anamnézou, zvyšuje sa relatívne riziko ischemickej CMP zhruba 1,3- až 1,8-násobne (Leško, Škorvánek , Háň, 2014). Preto nás zaujímalo kol'ko respondentov má pozitívnu rodinnú anamnézu. Zistili sme, že pozitívnu rodinnú anamnézu malo 35,89\% respondentov, bez pozoruhodností, resp. negatívnu rodinnú anamnézu malo $28,22 \%$ respondentov a 35,89\% respondentov rodinnú anamnézu nemalo zistenú.

Následne sme skúmali akú skupinu pacientov s prekonanou CMP tvoria pacienti s ischemickou CMP hospitalizovaných vo FN v Nitre privezených ZZS, ktorí podstúpili výkon v KC. Výsledky uvádzame v tabul'ke 2 a 3. 
Tabul'ka 2 Manažment a spolupráca s KOS všetkých CMP za roku 2017 podl'a pohlavia

\begin{tabular}{lll}
\hline Manažment respondenta & $\mathrm{n}$ & $\%$ \\
\hline spolupráca s KOS - primárny výjazd & 48 & $54,55 \%$ \\
\hline spolupráca s KOS - sekundárny výjazd & 32 & $36,36 \%$ \\
\hline hospitalizovaný pred výskytom CMP & 5 & $5,68 \%$ \\
\hline nezistené & 3 & $3,41 \%$ \\
\hline Spolu & $\mathbf{8 8}$ & $\mathbf{1 0 0 , 0 0 \%}$ \\
\hline
\end{tabular}

Legenda: $\mathrm{KOS}=$ Krajské operačné stredisko, $\mathrm{CMP}=$ cievna mozgová príhoda, $\mathrm{KC} \mathrm{NR}=$ Kardiocentrum Nitra

Z celkového súboru A 666 respondentov 88 respondentov (13,21\%) podstúpilo výkon v KC v Nitre. Z tohto počtu bolo do KC transportovaných 48 respondentov (54,55\%) ako primárny výjazd (či už prostredníctvom RLP alebo RZP) a 32 respondentov (36,36\%) ako sekundárny výjazd. V prípade sekundárneho výjazdu boli respondenti pred zákrokom v KC hospitalizovaní prevažne ako akútny príjem v zdravotníckom zariadení vo svojom regióne.

Tabul'ka 3 Výkon v KC NR

\begin{tabular}{lll}
\hline Výkon v KC NR & $\mathrm{n}$ & $\mathrm{r}$ \\
\hline úspešný & 72 & $81,82 \%$ \\
\hline neúspešný & 16 & $18,18 \%$ \\
\hline Spolu & $\mathbf{8 8}$ & $\mathbf{1 0 0 , 0 0 \%}$ \\
\hline
\end{tabular}

Legenda: KC NR = Kardiocentrum Nitra

Z uvedeného vyplýva, že viac ako $80 \%$ výkonov realizovaných u pacientov po CMP v KC NR boli klasifikované ako úspešné a teda môžeme povedat', že prišlo k úplnej alebo aspoň $\mathrm{k}$ čiastočnej rekanalizácii okludovanej cievy. $\mathrm{V}$ prípade neúspechu bola príčina hlavne $\mathrm{v}$ anatomických pomeroch, ktoré spôsobili nemožnost' prístupu k oklúzii danej cieve.

Poslednou otázkou bolo zistit’ akú skupinu pacientov s prekonanou CMP hospitalizovaných vo FN v Nitre tvoria pacienti s diagnosticky preukázanou prítomnost' Fabryho choroby prostredníctvom vyšetrenia suchej kvapky krvi. Z celkového počtu 666 pacientov, ktorí boli hospitalizovaní vo FN v Nitre v období od 1.1.2017 do 31.12.2017 bolo pre podozrenie na Fabryho chorobu vyšetrených 43 pacientov. Z tohto počtu však boli do nášho súboru zaradení iba tí pacienti, ktorí okrem kritéria veku, ktorí ich radí do skupiny pre vyšetrenie na podozrenie Fabyho choroby, prekonali aj CMP. Preto bolo do nášho súboru B zaradených 39 respondentov. 
Tabul'ka 4 Diagnosticky dokumentovaná FCH

\begin{tabular}{lll}
\hline Diagnóza FCH & $\mathrm{n}$ & $\mathrm{r}$ \\
\hline pozitívna, resp. patologická hodnota & 1 & $5,13 \%$ \\
\hline negatívna & 24 & $79,49 \%$ \\
\hline nezistená z dôvodu chybnej vzorky & 6 & $15,38 \%$ \\
\hline Spolu & $\mathbf{3 9}$ & $\mathbf{1 0 0 , 0 0 \%}$ \\
\hline
\end{tabular}

Legenda: $\mathrm{FCH}=$ Fabryho choroba

Diagnostika Fabryho choroby prebieha pomocou vyšetrenia suchej kvapky krvi. Metoda suchej kvapky krvi (DBS - dried blood spot), ktorú objavil v roku 1963 Robert Guthrie, je jednoduchou, miniinvazivnou diagnostickou metódou. Pre diagnostiku vrodených metabolických porúch sa používa už viac ako 50 rokov. „Metoda suchej kvapky spočíva v prenesení kvapky krvi na filtrační papier, usušení a doprave do laboratória ku stanoveniu aktivity enzýmu. Iba v prípade nízkej hodnoty sa stanovuje aktivita v plazme, poprípade leukocytoch a fibroblastoch" (Golán̆, 2012, s. 380). Výsledky vyšetrení preukázalo, že z nášho súboru bola iba u dvoch $(5,13 \%)$ respondentov znížená hladina enzýmu na patologickú hodnotu. Avšak toto zníženie nevylúčilo reziduálnu aktivitu enzýmu a bolo bez prítomnosti mutácie. „Znížená aktivita, či úplná absencia aktivity tohto enzymu, postihuje metabolismus glykolipidov a glykoproteinov" (Lacina, Kodet, 2017, s. 59). V oboch prípadoch išlo o mužov. U žien sa hodnoty enzýmu často prekrývajú s hodnotami u zdravej populácie, diagnózu musí preto potvrdit' molekulárne genetické stanovenie mutácie (Goláň, 2012). U 79,49\% respondentov bola hladina enzýmu nad požadovanou hladinou a teda ochorenie sa nepotvrdilo. U 15,38\% respondentov vyšetrenie bolo pre znehodnotenie vzorky doplnené o podrobnejšiu genetickú analýzu a môžeme predpokladat', že výsledok bol negatívny.

\section{ZÁVER}

CMP patria medzi najfrekventovanejšie diagnózy spôsobujúce trvalú invaliditu a mortalitu. V rozvinutých krajinách ich možno považovat’ dokonca za najčastejšiu diagnózu vedúcu k trvalej invalidite (Kucharík, Tomka, Vulev, 2016). Akútne mozgové infarkty u mladých l'udí sú zriedkavé a ich etiológiu sa často krát nepodarí presne určit'. Tento výskyt CMP u mladších obyvatel'ov môžeme pripisovat' nedostatočnej primárnej prevencii a životnému štýlu, ale je potrebné pamätat' na možnost' výskytu FCH ako ochorenia, ktoré je spojené s ukladaním glykosfingolipidov v tkanivách a prejavuje sa angiokeratómami, poškodením obličiek, myokardiálnymi a mozgovými ischemickými léziami (Štofková, 2015; Kalvach, 2010).

\section{LITERATÚRA}

Brozman, M. (2008). Liečba NCMP v akútnom štádiu-odborné usmernenie. Via practica, 12-16.

Brozman, M. (2014). Systémová intravenózna trombolýza mozgových infarktov-najlepšia alternatíva liečby. Neurologie pro praxi, 120-124.

Dobiáš, V. (2017). 5P - Prvá pomoc pre pokročilých poskytovatel’ov. Dixit, 2017.

Gogolák, I. (2010). Diagnostika a liečba náhlych cievnych mozgových príhod. Vaskulárna medicína, 2(2), 56-62. 
Goláň, M. L. (2012). Fabryho choroba-lysozomální onemocnění ze strádání s multiorgánovým postižením. Interni medicína pro praxi, 14(10), 378-382.

Kákošová, V. (2007). Fabryho choroba-lysozomální onemocnění ze střádání s multiorgánovým postižením. Klinická farmakologie a farmacie; 21, 27-30.

Kalvach, P., Adam, P., Angerová, I., Bauer J., Cséfalvay, Z., Feigin, V. ... \& Zveřina, E. (2010). Mozkové ischémie a hemoragie. 3. preprac. a dopl. vyd. Praha: Grada.

Kucharík, M., Tomka, J., \& Vulev, I. Periprocedurálny neurologický manažment operácií a endovaskulárnych intervencií na prívodných mozgových tepnách. Vaskulárna medicína. 8(1), 14-16.

Lacina, M. L., \& Kodet, M. O. (2017) Fabryho choroba-přehled pro dermatovenerologa. Dermatologie pro praxi, 11(2), 58-62.

Leško, M. N., Škorvánek, M. M., \& Haň, M. V. (2014). Špecifiká cerebrovaskulárnych ochorení u žien. Neurológia pre prax, 15 (6), 285-288.

Modravý, J. (2006). Diagnostika a liečba cievnej mozgovej príhody. Solen. Via practica. 3 (5), 229-232.

Pekárková, I. (2015). Cévní mozkové příhody. Rokyta, R. a kol. Fyziologie a patologická fyziologie. Praha: Grada Publishing, a. s.

Solgajová, A., Sollár, T., Vorosova, G., \& Zrubcova, D. (2017). Personality as significant predictor of post-stroke anxiety. Neuroendocrinology Letters, 38(4), 290-294.

Solgajová, A., Vörösová, G., Zrubcová, D., Semanišinová, M. (2016). Uplatnenie ošetrovatel'ských intervencií v starostlivosti o pacienta s cievnou mozgovou príhodou. Intervence v domácí zdravotní péči : recenzovaný vědecký sborník vydaný $k$ př́ležitosti Mezinárodního dne lidských práv a 23. výročí založeni Agentury domáci zdravotni péče Pracoviště ošetrovatelské péče v Hradci Králové Česká republika; Hradec Králové: Pracoviště ošetřovatelské péče. 84-97.

Spada, M., Pagliardini, S., Yasuda, M., Tukel, T., Thiagarajan, G., Sakuraba, H., ... \& Desnick, R. J. (2006). High incidence of later-onset Fabry disease revealed by newborn screening. The American Journal of Human Genetics, 79(1), 31-40.

Školoudík, D. (2014). Rekanalizační léčba mozkové ischemie-jak dál? Neurologie pro praxi, 15(3), 125130.

Štofková, A. (2015). Fyziologie a patofyziologie metabolismu a výživy. Rokyta, R. a kol. Fyziologie a patologická fyziologie pro klinickou praxi. Praha: Grada. 


\section{INCIDENCE OF STROKE IN PATIENTS HOSPITALISED IN FACULTY HOSPITAL NITRA}

Abstract: Objective: In the study, the author focuses on Fabry disease as a multisystem disease which can have as one of the predisposing factors influence on occurrence of stroke. Methods: The author set an objective to study a sample of patients hospitalised in the FH Nitra by a retrospective content analysis in a defined period of time. Results: Out of 666 respondents who suffered stroke in 2017 and were hospitalised in the FH in Nitra, there were 571 respondents (85.74 \%) with ischemic stroke, 89 respondents $(13.36 \%)$ with haemorrhagic stroke and six respondents $(0.90 \%)$ with stroke, not specified as haemorrhage or infarction. In terms of gender, we found out that there were 323 men (56.57\%) and 248 women (43.43\%) who suffered ischemic stroke. Out of 666 respondents of the sample A, there were 627 respondents $(94.14 \%)$ hospitalised with newly found stroke and in 39 respondents (5.86 \%) stroke recurred in 2017. Conclusion: Acute cerebral infarctions are the third most common cause of death and the most common cause of premature disability. An annual incidence increases with age. In young people, however, we must remember other than usual causes and one of them is Fabry disease.

Keywords: Fabry disease, stroke, ischemic stroke, haemorrhagic stroke, $\alpha$ galactosidase A, glycosphingolipids 